\title{
The Potential Downside of Having Non-Family Board Members
}

\author{
Alfredo De Massis (Free University of Bozen-Bolzano)
}

KEYWORDS: Family Business, Board of directors, Governance.

Link to video

\section{By Alfredo DeMassis, Lorraine Uhlaner, Ann Jorrissen and Yan Du}

It's been generally accepted that family firms benefit from the perspectives of outsiders on the board of directors. Outsiders can bring new knowledge and objectiveness to family firm governance. But our survey of 561 small- and medium-sized Belgian firms showed a potential downside: the presence of outsiders can be detrimental if CEOs are more reluctant to talk about finances, market position, strategy and efficiency with the entire board. This was especially true at companies where the board met infrequently and where the CEO wanted to keep tight control over operations and the flow of information. The unhappy result: the board became disengaged, and firm performance suffered.

The video summarizes our findings, and you can download our research paper here (https://journals.sagepub.com/doi/full/10.1177/0018726 720932985) . 